\title{
Bromine measurements in ozone depleted air over the Arctic Ocean
}

\author{
J. A. Neuman ${ }^{1,2}$, J. B. Nowak ${ }^{1,2}$, L. G. Huey ${ }^{3}$, J. B. Burkholder ${ }^{2}$, J. E. Dibb ${ }^{4}$, J. S. Holloway ${ }^{1,2}$, J. Liao ${ }^{3}$, J. Peischl ${ }^{1,2}$, \\ J. M. Roberts ${ }^{2}$, T. B. Ryerson ${ }^{2}$, E. Scheuer ${ }^{4}$, H. Stark ${ }^{1,2}$, R. E. Stickel ${ }^{3}$, D. J. Tanner ${ }^{3}$, and A. Weinheimer ${ }^{5}$ \\ ${ }^{1}$ Cooperative Institute for Research in Environmental Sciences, University of Colorado at Boulder, Boulder, Colorado, USA \\ ${ }^{2}$ Earth System Research Laboratory, NOAA, Boulder, Colorado, USA \\ ${ }^{3}$ School of Earth and Atmospheric Science, Georgia Institute of Technology, Atlanta, Georgia, USA \\ ${ }^{4}$ Institute for the Study of Earth, Oceans, and Space, University of New Hampshire, Durham, New Hampshire, USA \\ ${ }^{5}$ Atmospheric Chemistry Division, National Center for Atmospheric Research, Boulder, Colorado, USA
}

Received: 7 January 2010 - Published in Atmos. Chem. Phys. Discuss.: 10 February 2010

Revised: 5 June 2010 - Accepted: 21 June 2010 - Published: 16 July 2010

\begin{abstract}
In situ measurements of ozone, photochemically active bromine compounds, and other trace gases over the Arctic Ocean in April 2008 are used to examine the chemistry and geographical extent of ozone depletion in the arctic marine boundary layer (MBL). Data were obtained from the NOAA WP-3D aircraft during the Aerosol, Radiation, and Cloud Processes affecting Arctic Climate (ARCPAC) study and the NASA DC-8 aircraft during the Arctic Research of the Composition of the Troposphere from Aircraft and Satellites (ARCTAS) study. Fast (1 s) and sensitive (detection limits at the low pptv level) measurements of $\mathrm{BrCl}$ and $\mathrm{BrO}$ were obtained from three different chemical ionization mass spectrometer (CIMS) instruments, and soluble bromide was measured with a mist chamber. The CIMS instruments also detected $\mathrm{Br}_{2}$. Subsequent laboratory studies showed that $\mathrm{HOBr}$ rapidly converts to $\mathrm{Br}_{2}$ on the Teflon instrument inlets. This detected $\mathrm{Br}_{2}$ is identified as active bromine and represents a lower limit of the sum $\mathrm{HOBr}+\mathrm{Br}_{2}$. The measured active bromine is shown to likely be $\mathrm{HOBr}$ during daytime flights in the arctic. In the MBL over the Arctic Ocean, soluble bromide and active bromine were consistently elevated and ozone was depleted. Ozone depletion and active bromine enhancement were confined to the MBL that was capped by a temperature inversion at $200-500 \mathrm{~m}$ altitude. In ozonedepleted air, BrO rarely exceeded 10 pptv and was always substantially lower than soluble bromide that was as high as 40 pptv. $\mathrm{BrCl}$ was rarely enhanced above the 2 pptv detection limit, either in the MBL, over Alaska, or in the arctic free troposphere.
\end{abstract}

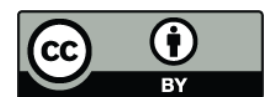

Correspondence to: J. A. Neuman (andy.neuman@noaa.gov)

\section{Introduction}

Low ozone mixing ratios over the Arctic Ocean region in the spring have been observed for nearly three decades (Oltmans, 1981). Model studies and measurements of ozone, halogen compounds, and volatile organic compounds that react with halogens have shown that bromine from the Arctic Ocean causes ozone depletion in the springtime arctic boundary layer (Simpson et al., 2007, and references therein). Atmospheric concentrations of photochemically active bromine species are elevated by heterogeneous chemistry that converts condensed phase bromine to volatile and photolabile species such as $\mathrm{Br}_{2}$ (Fan and Jacob, 1992). Photolysis of either $\mathrm{Br}_{2}$ or $\mathrm{HOBr}$ then forms $\mathrm{Br}$ atoms. In seawater, chloride is 700 times more abundant than bromide. Yet in the atmosphere over the arctic in spring, the selective liberation of bromine from sea ice causes $\mathrm{Br}$ atoms to exceed $\mathrm{Cl}$ atoms by factors of hundreds, as shown by measurements of VOC ratios (Jobson et al., 1994; Impey et al., 1999; Keil and Shepson, 2006). Br atoms react with ozone by

$\mathrm{Br}+\mathrm{O}_{3} \rightarrow \mathrm{BrO}+\mathrm{O}_{2}$

and catalytic ozone destruction occurs if $\mathrm{Br}$ atoms are regenerated by $\mathrm{BrO}$ self-reaction or reaction with $\mathrm{HO}_{2}$. $\mathrm{BrO}$ produced from the reaction of $\mathrm{Br}$ and ozone has been observed in arctic regions and provides further confirmation of bromineinduced ozone destruction (Hausmann and Platt, 1994). In the springtime arctic, a stable boundary layer isolates the air in the lowest several hundred meters of the atmosphere from the free troposphere above. This reduces dilution of ozonedepleted air in the marine boundary layer (MBL) with ozonerich air in the free troposphere and further allows bromine species to build to high levels.

Published by Copernicus Publications on behalf of the European Geosciences Union. 
Most arctic studies of ozone depletion have been conducted over land from coastal ground sites near ocean source regions of halogens (Barrie et al., 1988; Simpson et al., 2007, and references therein). Back trajectories and ozone observations have shown that the predominant transport pathway for ozone depleted air arriving at arctic ground sites is over the Arctic Ocean, suggesting that ozone depletion chemistry occurs over the ocean (Bottenheim and Chan, 2006). The few measurements obtained directly over Arctic Ocean ice have shown that ozone depletion is persistent in the spring (Hopper et al., 1998). Sustained ozone depletion over arctic ice has been observed at high latitudes $\left(81-88^{\circ} \mathrm{N}\right)$ from a ship that drifted while frozen in the Arctic Ocean (Bottenheim et al., 2009). Ozone depletion and bromine chemistry in the lower troposphere at high latitudes also have been studied using satellite measurements of $\mathrm{BrO}$ combined with model calculations (Zeng et al., 2003; Simpson et al., 2007, and references therein; Jones et al., 2009).

Measurements from aircraft, which permit investigations over these ocean regions where ozone depletion originates, also have shown that ozone depletion is ubiquitous over the Arctic Ocean in spring (Leaitch et al., 1994; Hopper et al., 1998). Large regions with both major $\left(\mathrm{O}_{3}<4 \mathrm{ppbv}\right)$ and partial $\left(4<\mathrm{O}_{3}<20 \mathrm{ppbv}\right)$ ozone depletions were detected by aircraft measurements over the Canadian Arctic, the Arctic Ocean north of Greenland, and occasionally at more southern latitudes (Ridley et al., 2003). In that study, ozone depletion was observed regularly and was associated with increased levels of soluble bromide. The largest levels of soluble bromide were in the northernmost ozone-depleted air, but interestingly not in the layers with the least ozone. The relationship between ozone and bromine is investigated further here.

Arctic ozone depletion chemistry needs to be better understood, since it may have important regional environmental consequences. The presence of bromine and the depletion of ozone alter the oxidizing characteristics of the atmosphere to make the arctic a sink for some compounds. Elemental mercury $(\mathrm{Hg})$, which is long-lived and distributed globally, is oxidized to reactive forms by $\mathrm{Br}$ atoms (Donohoue et al., 2006). This reactive gaseous mercury deposits to surfaces more readily than elemental $\mathrm{Hg}$ and could collect in arctic regions (Steffen et al., 2008, and references therein).

Although severe ozone depletion caused by halogen chemistry is usually confined to a thin layer of the atmosphere over the polar oceans and occurs primarily in the spring, the same processes may occur throughout the year over all oceans (Simpson et al., 2007, and references therein; Mahajan et al., 2010). Understanding the processes that cause ozone depletion in the arctic can reveal whether these reactions substantially affect global ozone concentrations. Ozone reductions caused by reactive halogens have been modeled to occur throughout the troposphere (Yang et al., 2005) and in polluted marine air masses transported over the ocean (Sander and Crutzen, 1996). Experimental verification of these model results regarding halogen chemistry is challenging. Although several bromine-containing compounds are expected to be elevated in air masses where bromine-induced ozone destruction is important, measurement capabilities for low levels of inorganic bromine-containing molecules are limited primarily to $\mathrm{BrO}$ (Read et al., 2008; Platt and Honninger, 2003). In particular, $\mathrm{HBr}, \mathrm{BrO}, \mathrm{HOBr}, \mathrm{Br}_{2}$, and $\mathrm{Br}$ are predicted to be elevated at some point during ozone depletion, and their abundance indicates the temporal evolution of the ozone depletion chemistry (Lehrer et al., 2004; Calvert and Lindberg, 2003; Martinez et al., 1999; Sander and Crutzen, 1996; Evans et al., 2003; Fan and Jacob, 1992). Extending the limited geographical range of bromine observations and number of measured bromine compounds will provide experimental evidence for the effect of reactive halogens upon global lower tropospheric ozone abundance.

This study examines ozone depletion and bromine abundance over the Arctic Ocean near Alaska. New techniques for rapidly detecting low concentrations of $\mathrm{Br}_{2}, \mathrm{HOBr}, \mathrm{BrO}$, and $\mathrm{BrCl}$ are developed. The extent and causes of ozone depletion in the springtime arctic are investigated with expanded capabilities for speciating inorganic bromine.

\section{Measurements}

Aircraft measurements were performed over the Arctic Ocean in April 2008 as part of the Polar Study using Aircraft, Remote Sensing, Surface Measurements, and Models of Climate, Chemistry, Aerosols, and Transport (POLARCAT) during the International Polar Year. Data were obtained from the NOAA WP-3D aircraft during the Aerosol, Radiation, and Cloud Processes affecting Arctic Climate (ARCPAC) experiment and the NASA DC-8 aircraft during the Arctic Research of the Composition of the Troposphere from Aircraft and Satellites (ARCTAS) experiment. Flights targeted many different air mass types to address the multiple goals of the ARCPAC (Brock et al., 2010) and ARCTAS studies (Jacob et al., 2010). A small fraction of the WP-3D (20\%) and DC-8 (10\%) arctic flights were dedicated to sampling in or near the MBL over the Arctic Ocean to examine halogen chemistry. The WP-3D measurements are described in detail here and the data are available at http://www.esrl.noaa.gov/csd/arcpac/. The DC-8 measurements are briefly summarized, and the data are available at http://www-air.larc.nasa.gov/data.htm.

\subsection{Aircraft sampling platforms}

The NOAA WP-3D aircraft flew over the Arctic Ocean on five flights that departed from Fairbanks, Alaska. The flights were performed during the day on 12,15, 18, 19, and 21 April 2008 (Fig. 1). Over sea ice, the WP-3D typically flew between $100-160 \mathrm{~m}$ altitude, with occasional dips to $60 \mathrm{~m}$. Air was sampled above the MBL in frequent altitude 
profiles and higher altitude flight legs up to $7.4 \mathrm{~km}$. Approximately 20-90 min of flight time was dedicated to sampling in the MBL on each eight hour flight. Most of the MBL studies were conducted over the Beaufort and Chukchi Seas adjacent to the northern coastline of Alaska.

The NASA DC-8 aircraft conducted seven flights in the arctic region between 4 April and 17 April 2008. Flight altitudes in the MBL over the Arctic Ocean were typically $100 \mathrm{~m}$. Although the DC-8 devoted less time to studies of halogen chemistry in the MBL, it covered a much larger area, with measurements at high latitudes all the way to the pole and further east over the Canadian Arctic.

In situ measurements were obtained from fast-response, high-sensitivity instruments. Complete instrument descriptions, as well as field intercomparison results, are detailed in ARCPAC and ARCTAS overview papers (Brock et al., 2010; Jacob et al., 2010). On the WP-3D, ozone was measured by chemiluminescence. The data were averaged to once per second with a 1 -sigma uncertainty of $\pm(4 \%+0.05)$ ppbv. Additional fast response measurements used to characterize the air masses included $\mathrm{SO}_{2}$ (uncertainty $\left.\pm(13 \%+0.55) \mathrm{ppbv}\right), \mathrm{CO}$ (uncertainty $\pm 3 \%$ ), $\mathrm{NO}$ (uncertainty $\pm(8 \%+0.02) \mathrm{ppbv}$ ), $\mathrm{NO}_{2}$ (uncertainty $\pm(10 \%+0.04)$ ppbv), and $\mathrm{NO}_{\mathrm{y}}$ (uncertainty $\pm(12 \%+0.05) \mathrm{ppbv})$. Measurements of actinic flux between 280 and $690 \mathrm{~nm}$ were performed both in the upward and downward looking directions at $1 \mathrm{~nm}$ resolution using two grating spectrometer/CCD systems (Stark et al., 2007). Photolysis rates for bromine compounds were calculated from the actinic flux measurements using literature values for the absorption cross-sections and quantum yields (Sander et al., 2006).

On the DC-8, soluble bromide was measured with a mist chamber. The species responsible for bromide in the mist chamber are uncertain but include inorganic bromine compounds $\mathrm{HBr}, \mathrm{HOBr}$, particulate bromide, and possibly $\mathrm{BrO}$ and $\mathrm{Br}_{2}$ (Ridley et al., 2003; Dibb et al., 2010; Liao et al., 2010). Each measurement averaged over $1.5 \mathrm{~min}$, with a 3 pptv detection limit and a 20-30\% uncertainty. Ozone was measured by chemiluminescence with $5 \%$ uncertainty, $<1 \mathrm{~s}$ time response, and $<0.1 \mathrm{ppbv}$ imprecision. The chemical ionization mass spectrometers (CIMS) (Huey, 2007) used to measured halogen species on both aircraft are described in detail below.

\subsection{CIMS halogen detection}

Fast response measurements of reactive halogen compounds were achieved using newly developed detection techniques. Gas phase reactive halogen compounds were measured by a CIMS instrument on the DC- 8 and by two independent CIMS instruments on the WP-3D. The CIMS techniques used here evolve from instruments that measure atmospheric $\mathrm{SO}_{2}$ (Kim et al., 2007) and peroxyacyl nitrates (Slusher et al., 2004), with modifications that exploit laboratory studies of ion-molecule reactions involving halogen compounds
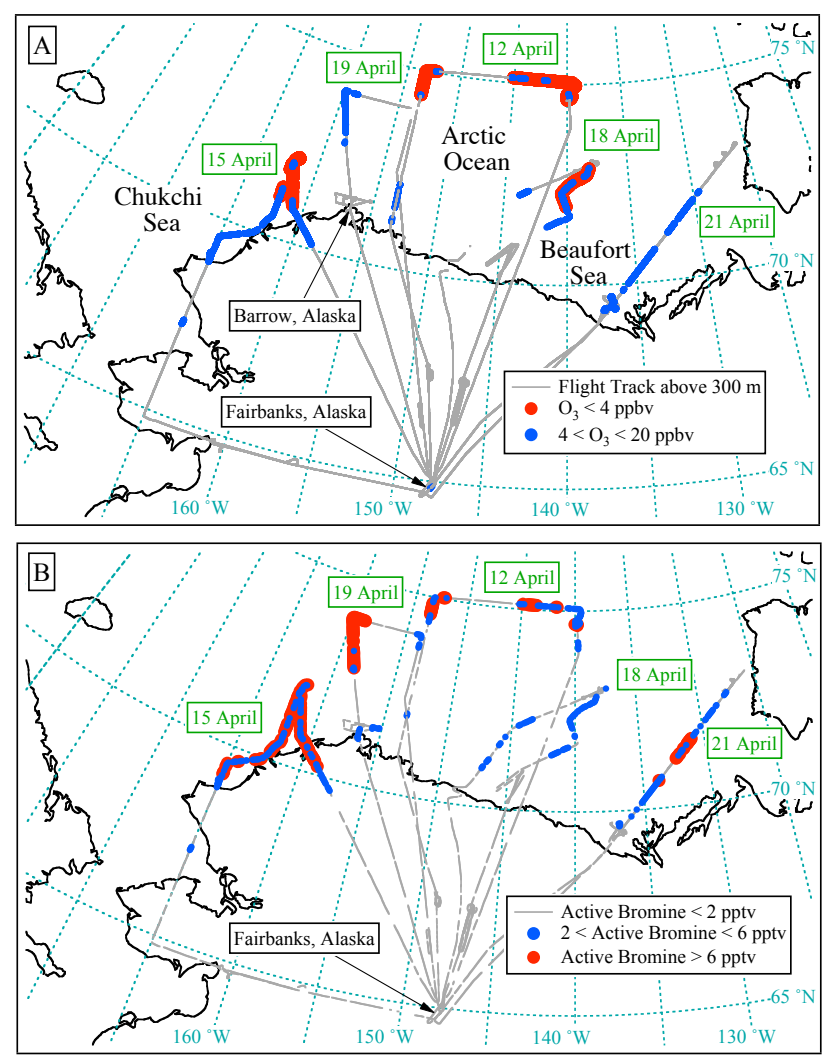

Fig. 1. (a) $1 \mathrm{~s}$ measurements of ozone on five WP-3D flights originating from Fairbanks, Alaska. Red circles are major ozone depletions, blue are partial ozone depletions, and no symbol represents ozone $>20$ ppbv. Gray lines indicate flight tracks over $300 \mathrm{~m}$ altitude. Gaps in the flight tracks (on 18 April, for example) indicate flight altitudes less than $300 \mathrm{~m}$ and ozone greater than 20 ppbv. (b) $10 \mathrm{~s}$ averages of active bromine, colored according to mixing ratio. Red markers show active bromine over 6 pptv, blue indicate active bromine between 2 and 6 pptv, and gray lines represent active bromine less than 2 pptv. The gaps occur when in-flight diagnostics were performed and active bromine was not measured.

(Huey et al., 1995; Roberts et al., 2008). Reagent ions are made in-flight and mixed with ambient air in a low-pressure flow tube, where ion-molecule reactions form unique product ions used to determine ambient mixing ratios. $\mathrm{Br}_{2}, \mathrm{BrCl}$, and $\mathrm{BrO}$ are measured using either $\mathrm{I}^{-}$or $\mathrm{SF}_{6}^{-}$reagent ions. The reagent and product ions are mass-filtered with quadrupole mass spectrometers and then counted with electron multiplier detectors. The air is admitted into the instruments through separate inlets by pulling flows of several standard liters per minute (slm) through heated $\left(\approx 30^{\circ} \mathrm{C}\right)$ tubes. All wetted inlet parts are made from perfluoroalkoxy (PFA) Teflon (abbreviated as Teflon below). The aircraft inlets are housed in winglets that extend perpendicular to the skin of the aircraft and beyond the aircraft boundary layer, with inlet tips that are $0.4 \mathrm{~cm}$ ID Teflon tubes. Total inlet lengths are less than 


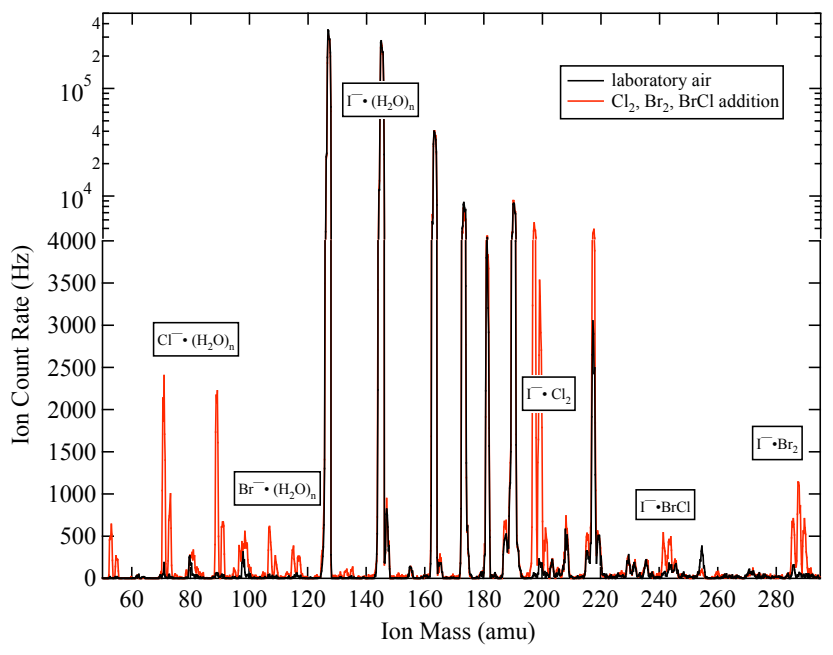

Fig. 2. Mass spectra for laboratory air admitted into a humidified flow tube with $\mathrm{I}^{-}$ions (black line). The ordinate is linear up to $4000 \mathrm{~Hz}$ and logarithmic above. The red line includes addition of 0.3 ppbv $\mathrm{Br}_{2}, 0.1 \mathrm{ppbv} \mathrm{BrCl}$, and $1.5 \mathrm{ppbv} \mathrm{Cl}_{2}$.

$1 \mathrm{~m}$ for each instrument, resulting in inlet residence times of tens of ms.

Instrument operation and diagnostics, including sampling, calibration, and zeroing, are given below for the WP-3D CIMS that uses $\mathrm{I}^{-}$ion chemistry. $\mathrm{I}^{-}$reagent ions are produced by flowing $2 \mathrm{slm} \mathrm{N}_{2}$ doped with $2.5 \mathrm{ppmv} \mathrm{CH}_{3} \mathrm{I}$ through a ${ }^{210} \mathrm{Po}$ radioactive source. The $\mathrm{CH}_{3} \mathrm{I}$ is obtained from a $5 \mathrm{sccm}$ flow of $0.1 \% \mathrm{CH}_{3} \mathrm{I}$ in $\mathrm{N}_{2}$. This ion flow is combined with $1.6 \mathrm{slm}$ ambient air in a $46-\mathrm{cm}$ long flow tube at 20 Torr. Adding a 20 -sccm $\mathrm{N}_{2}$ flow bubbled through distilled $\mathrm{H}_{2} \mathrm{O}$ humidifies the flow tube. Humidification increases the abundance of $\mathrm{I}^{-} \cdot \mathrm{H}_{2} \mathrm{O}$ cluster ions, which provide better sensitivity to halogen detection than $\mathrm{I}^{-}$alone.

$\mathrm{I}^{-} \cdot \mathrm{H}_{2} \mathrm{O}$ reacts with $\mathrm{Br}_{2}, \mathrm{BrCl}, \mathrm{Cl}_{2}$, and $\mathrm{BrO}$ to form clusters of $\mathrm{I}^{-}$with the halogen molecules. Since atomic I has no isotopes and a mass given by 127 atomic mass units (amu), and atomic $\mathrm{Br}$ and $\mathrm{Cl}$ have two naturally occurring isotopes $\left({ }^{79} \mathrm{Br}(50.7 \%),{ }^{81} \mathrm{Br}(49.3 \%)\right.$, and ${ }^{35} \mathrm{Cl}(75.8 \%)$, $\left.{ }^{37} \mathrm{Cl}(24.2 \%)\right)$, the cluster ions have simple but distinct isotope ratios. For example, $\mathrm{I}^{-} \cdot \mathrm{Br}_{2}$ clusters have three isotopes: $285 \mathrm{amu}(25 \%), 287 \mathrm{amu}(50 \%)$, and $289 \mathrm{amu}$ (25\%) (Fig. 2). These isotope patterns facilitate unambiguous identification of the ions. However, instrument sensitivity is reduced, since only one mass is measured at a time, and isotopes distribute the ion products over several masses simultaneously. Ions are monitored in flight in the following sequence: $127 \mathrm{amu}\left(\mathrm{I}^{-}\right)$for $100 \mathrm{~ms}, 145 \mathrm{amu}\left(\mathrm{I}^{-} \cdot \mathrm{H}_{2} \mathrm{O}\right)$ for $100 \mathrm{~ms}, 224 \mathrm{amu}\left(\mathrm{I}^{-} \cdot \mathrm{BrO}\right)$ for $500 \mathrm{~ms}, 243 \mathrm{amu}\left(\mathrm{I}^{-} \cdot \mathrm{BrCl}\right)$ for $500 \mathrm{~ms}$, and $287 \mathrm{amu}\left(\mathrm{I}^{-} \cdot \mathrm{Br}_{2}\right)$ for $500 \mathrm{~ms}$. Consequently, $\mathrm{BrO}, \mathrm{BrCl}$, and $\mathrm{Br}_{2}$ mixing ratios are determined once every $2 \mathrm{~s}$. $\mathrm{I}^{-}$and its water clusters are orders of magnitude more abundant than any other negative ions in the flow tube, with

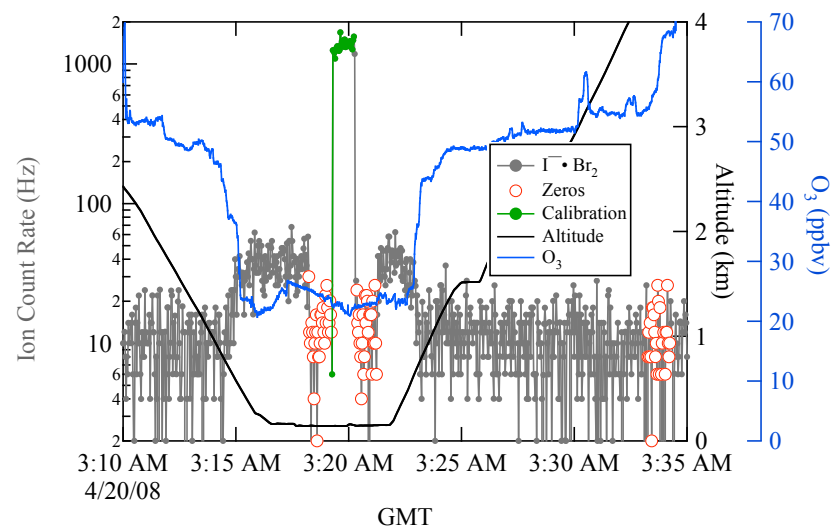

Fig. 3. $\mathrm{I}^{-} \cdot \mathrm{Br}_{2}$ signals recorded once every $2 \mathrm{~s}$ during ambient measurements (gray), calibration (green), and background determinations (red) over the Arctic Ocean on 19 April. Ozone is shown in blue and aircraft altitude in black.

$\mathrm{I}^{-}$and $\mathrm{I}^{-} \cdot \mathrm{H}_{2} \mathrm{O}$ ion count rates typically $400 \mathrm{kHz}$ (Figs. 2 and 4).

Entirely different ion chemistry and resulting product ions are used for halogen detection on the DC-8 and in the other WP-3D CIMS instrument. Nitrogen doped with $\mathrm{SF}_{6}$ is used to produce the $\mathrm{SF}_{6}^{-}$reagent ions. $\mathrm{SF}_{6}^{-}$is a reactive ion that was employed with the primary goal of measuring $\mathrm{SO}_{2}$, but it also reacts efficiently with halogen compounds to form negatively charged halogens by charge transfer. For example, $\mathrm{SF}_{6}^{-}$reacts with $\mathrm{BrO}$ to form $\mathrm{BrO}^{-}$. The operation of these two instruments is not detailed here, but they perform similarly to the WP-3D I- CIMS, with in-flight calibrations and background determinations as described below.

\subsection{Sensitivity}

Instrument sensitivity is determined in-flight by standard addition calibrations of $\mathrm{Br}_{2}$. The $\mathrm{Br}_{2}$ source is a commercial permeation device (Kin-tek USA). $20 \mathrm{sccm}$ of $\mathrm{N}_{2}$ continuously flows around a $\mathrm{Br}_{2}$ permeation tube that is pressure controlled at $2 \mathrm{~atm}$ and temperature controlled at $25^{\circ} \mathrm{C}$. The $\mathrm{Br}_{2}$ output was measured to be $12 \mathrm{ng} / \mathrm{min}$ by optical absorption at $404 \mathrm{~nm}$. At $40^{\circ} \mathrm{C}$, the measured output was $56 \mathrm{ng} / \mathrm{min}$, and $14 \%$ higher than the manufacturer's gravimetric determination of $49 \mathrm{ng} / \mathrm{min}$. The calibration gas is mixed with the 5-slm inlet airflow to give 340 pptv calibrations. $\mathrm{Br}_{2}$ is admitted into the inlet for 1 min approximately once per hour. The response to the calibration is rapid, with a $>90 \%$ rise and fall in $<2 \mathrm{~s}$ (Fig. 3). The sensitivity to $\mathrm{Br}_{2}$ detection averages 5 ion counts per second per pptv (Hz/pptv). The DC-8 and the other WP-3D CIMS instrument sensitivities were determined similarly.

The sensitivity to other halogen compounds was determined in the laboratory both before and after the field study, and in-flight sensitivity is calculated from the laboratory ratios to $\mathrm{Br}_{2}$ sensitivity. $\mathrm{Cl}_{2}$ sensitivity was determined using 
permeation devices and compressed gas mixtures containing 3-5 ppmv $\mathrm{Cl}_{2}$ in $\mathrm{N}_{2}$. Placing $\mathrm{Br}_{2}$ and $\mathrm{Cl}_{2}$ permeation tubes in a single oven at $40^{\circ} \mathrm{C}$ made $\mathrm{BrCl}$. The $\mathrm{BrCl}$ output was related to $\mathrm{Br}_{2}$ by the reduction in $\mathrm{Br}_{2}$ when $\mathrm{Cl}_{2}$ was added and $\mathrm{BrCl}$ was formed, assuming quantitative conversion of $\mathrm{Br}_{2}$ to $\mathrm{BrCl}$. The sensitivities to $\mathrm{Cl}_{2}$ and $\mathrm{BrCl}$ detection at the most abundant product isotopes $\left(\mathrm{I}^{-} \cdot{ }^{.70} \mathrm{Cl}_{2}(58 \%)\right.$, $\left.\mathrm{I}^{-.}{ }^{116} \mathrm{BrCl}(50 \%), \mathrm{Fig} .2\right)$ are approximately equal to that for $\mathrm{Br}_{2}\left(\mathrm{I}^{-} .{ }^{160} \mathrm{Br}_{2}, 50 \%\right)$. BrO was made by flowing $\mathrm{Br}_{2}$ in $\mathrm{He}$ through a microwave discharge to make $\mathrm{Br}$ atoms (Orlando et al., 1991), and then ozone was added after the discharge to make $\mathrm{BrO}$ by Reaction (1). The sensitivity is determined by comparing $\mathrm{BrO}$ to $\mathrm{Br}_{2}$ variations when the discharge and ozone were modulated. Ozone addition lowers the $\mathrm{Br}_{2}$ output since $\mathrm{Br}$ recombination that regenerates $\mathrm{Br}_{2}$ is reduced by the loss of $\mathrm{Br}$ to $\mathrm{BrO}$ (Reaction 1). Similarly, operation of the microwave discharge reduces $\mathrm{Br}_{2}$ signals. These experiments place upper and lower bounds on the $\mathrm{BrO}$ sensitivity relative to $\mathrm{Br}_{2}$, since $\mathrm{Br}$ atoms may be lost to surfaces without $\mathrm{Br}_{2}$ reformation. Using $\mathrm{I}^{-}$ion chemistry, the sensitivity to $\mathrm{BrO}$ detection is approximately half the $\mathrm{Br}_{2}$ sensitivity. $\mathrm{BrO}$ and $\mathrm{BrCl}$ measurement uncertainties are larger since their calibration magnitudes are not independently measured but are derived from changes in $\mathrm{Br}_{2}$ signals.

\subsection{Background determination and measurement uncertainty}

The instrument background is measured by sampling ambient air through a scrubber that removes halogen compounds without otherwise changing the ambient air. Every $15 \mathrm{~min}$, the Teflon valve located at the inlet tip (see Fig. 1 in the work of Neuman et al., 2002) was actuated and ambient air was directed through a scrubber before entering the inlet. After $1 \mathrm{~min}$, the valve was switched to bypass the scrubber and directly sample ambient air. The scrubbing material in the WP-3D I- CIMS is untreated fine Pyrex glass wool that readily removes all $\mathrm{Br}_{2}$ and $\mathrm{BrO}$. Other tested materials, including steel wool and nylon wool, do not remove $\mathrm{Br}_{2}$ completely. Activated charcoal, which is used as a scrubbing material in the other two CIMS instruments, effectively removes $\mathrm{Br}_{2}$ from a gas stream, but it also removes many other compounds.

Background signal levels at the ion masses used for halogen detection were low. The measurement sequence shown in Fig. 3 illustrates the response to in-flight background determinations at ion mass 287 used for $\mathrm{Br}_{2}$ detection. The open red circles indicate when ambient air was directed through the glass wool filter. Importantly, the instrument background did not change with altitude and remained low $(\approx 2$ pptv) and stable. BrO background levels were also consistently a few pptv. $\mathrm{BrCl}$ backgrounds were sometimes higher and more variable, causing greater uncertainty in the $\mathrm{BrCl}$ measurements. The measured background values for each ion mass are subtracted from the total signal at that mass to determine ambient mixing ratios. Although sensitivity to $\mathrm{Cl}_{2}$ is high, occasional rapid and large changes in the background at $197 \mathrm{amu}\left(\mathrm{I}^{-} \cdot \mathrm{Cl}_{2}\right)$ prevented accurate quantification of $\mathrm{Cl}_{2}$ at levels less than a few hundred pptv. Hence, $\mathrm{Cl}_{2}$ mixing ratios are not determined. The interferences at the masses used for $\mathrm{BrCl}$ and $\mathrm{Cl}_{2}$ detection have not been identified, but the high background variability was associated with rapidly changing ambient conditions during aircraft altitude profiles.

Imprecision, uncertainty in calibration addition and response, and background uncertainty contribute to total measurement uncertainties. Overall measurement uncertainty for $2 \mathrm{~s}$ data from the WP-3D I- CIMS is $\pm(15 \%+2)$ pptv for $\mathrm{Br}_{2}$ detection, and $\pm(40 \%+3)$ pptv for $\mathrm{BrO}$ and $\mathrm{BrCl}$ detection. Greater uncertainties for $\mathrm{BrO}$ and $\mathrm{BrCl}$ detection are caused by the additional uncertainty in determining $\mathrm{BrO}$ and $\mathrm{BrCl}$ calibration magnitudes (discussed above) and the higher and more variable background levels. The $\mathrm{SF}_{6}^{-} \mathrm{CIMS}$ instruments on the WP-3D and DC-8 also detected $\mathrm{BrO}$ and $\mathrm{Br}_{2}$. The sensitivity to $\mathrm{Br}_{2}$ detection using $\mathrm{SF}_{6}^{-}$was better than $4 \mathrm{~Hz} /$ pptv for both instruments. The DC- 8 CIMS measured $\mathrm{BrO}$ on two flights and $\mathrm{Br}_{2}$ on all seven arctic flights, with measurements once every $30 \mathrm{~s}$.

\subsection{Selectivity}

Bromine speciation is achieved by exploiting ion chemistry to detect each bromine-containing compound at a unique mass, as described above. The distinct isotopic signatures from bromine-containing compounds reduce ambiguity in ion identification (Fig. 2). Additionally, the product ions are at high masses and far from interfering ions or fragments of ion clusters. However, measuring highly reactive species is subject to sampling artifacts, including reaction on instrument surfaces that cause loss or chemical conversion of compounds. Laboratory tests showed that sampling air through the Teflon inlet did not introduce temporary retention or loss of $\mathrm{BrO}, \mathrm{BrCl}$, or $\mathrm{Br}_{2}$. But experiments conducted after the field campaign showed that $\mathrm{HOBr}$ readily converts to $\mathrm{Br}_{2}$ on the aircraft inlets used here. This conversion is similar to the efficient uptake of $\mathrm{HOBr}$ onto salt solutions (Fickert et al., 1999) and other surfaces (Mochida et al., 1998) that have been shown to produce gas phase $\mathrm{Br}_{2}$.

The conversion of $\mathrm{HOBr}$ to $\mathrm{Br}_{2}$ is quantified by synthesizing and measuring $\mathrm{HOBr}$ and studying its behavior on inlet surfaces. Gas phase $\mathrm{HOBr}$ is produced by liberating $\mathrm{HOBr}$ formed in solution by $\mathrm{Br}_{2}$ hydrolysis (Eigen and Kustin, 1962) in the reaction

$\mathrm{Br}_{2}+\mathrm{H}_{2} \mathrm{O} \Leftrightarrow \mathrm{HOBr}+\mathrm{Br}^{-}+\mathrm{H}^{+}$

$\mathrm{Br}_{2}$ hydrolysis is performed by flowing $4 \mathrm{sccm}$ humidified $\mathrm{N}_{2}$ and 0.2 ppmv $\mathrm{Br}_{2}$ in $30 \mathrm{sccm} \mathrm{N}_{2}$ over glass beads coated with $\mathrm{AgNO}_{3}$. The $3 \mathrm{~mm}$ diameter glass beads are contained in a $5-\mathrm{cm}$ long, $1-\mathrm{cm}$ ID, Teflon tube. Teflon fittings connect to $0.32 \mathrm{~cm}$ OD Teflon supply and delivery lines. $\mathrm{Br}_{2}$ hydrolyzes on the wet glass beads, and the resulting $\mathrm{Br}^{-}$is 


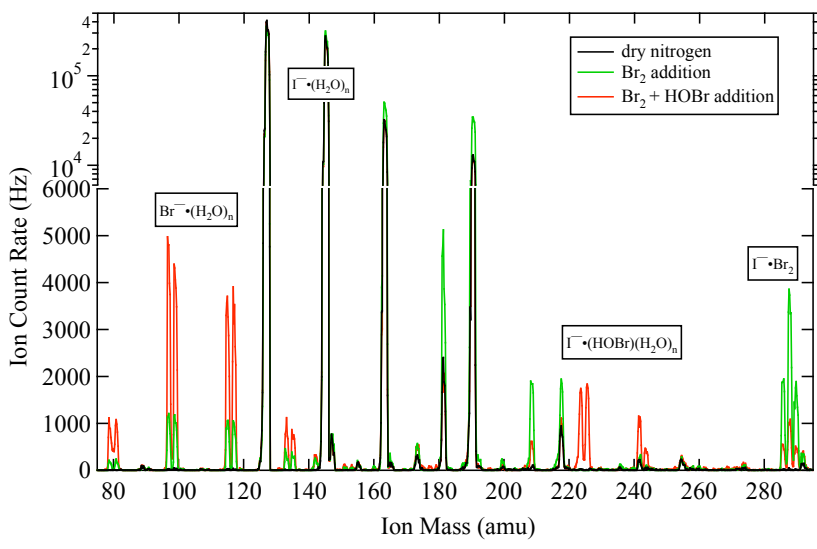

Fig. 4. Mass spectra for dry $\mathrm{N}_{2}$ (black), dry $\mathrm{N}_{2}$ with 1 ppbv $\mathrm{Br}_{2}$ (green), and dry $\mathrm{N}_{2}$ with 0.3 ppbv $\mathrm{Br}_{2}$ and $1.5 \mathrm{ppbv} \mathrm{HOBr}$ (red) mixed with $\mathrm{I}^{-}$in a humidified flow tube. The ordinate is linear up to $6000 \mathrm{~Hz}$ and logarithmic above.

removed by the formation of $\mathrm{AgBr}$. This drives the hydrolysis equilibrium toward $\mathrm{HOBr}$ formation, so that much of the $\mathrm{Br}_{2}$ is converted to gas phase $\mathrm{HOBr}$. At the exit of the cell containing the $\mathrm{AgNO}_{3}$-coated beads, the 34 -sccm N $\mathrm{N}_{2}$ flow typically has $20 \mathrm{ppbv} \mathrm{Br}_{2}$ and $100 \mathrm{ppbv} \mathrm{HOBr}$. Mixing this flow into a several slm inlet flow dilutes $\mathrm{Br}_{2}$ and $\mathrm{HOBr}$ to hundreds of pptv in the instrument.

$\mathrm{HOBr}$ is detected by the CIMS instrument using the same $\mathrm{I}^{-}$ion chemistry described above. Figure 4 shows laboratory mass spectra of $\mathrm{I}^{-}$ion chemistry with $\mathrm{HOBr}$ and $\mathrm{Br}_{2}$ in $\mathrm{N}_{2}$. $\mathrm{HOBr}$ reacts with $\mathrm{I}^{-} \cdot \mathrm{H}_{2} \mathrm{O}$ to form $\mathrm{I}^{-} \cdot \mathrm{HOBr}$ cluster ions (223 and $225 \mathrm{amu}) . \mathrm{Br}^{-}$and its water clusters are also formed (red peaks at masses 79 and 81 in Fig. 4). The efficient reaction channel that forms $\mathrm{Br}^{-}$causes the sensitivity to $\mathrm{HOBr}$ (for detection at $\mathrm{I}^{-} \cdot \mathrm{HOBr}$ ) to be approximately one third that for $\mathrm{Br}_{2}$ detection. $\mathrm{Br}^{-}$ions are not used for $\mathrm{HOBr}$ detection since they do not uniquely represent a single bromine compound. For example, $\mathrm{Br}_{2}$ also reacts with $\mathrm{I}^{-}$to form $\mathrm{Br}^{-}$(green peaks at masses 79 and 81 in Fig. 4), although with much less efficiency than the clustering of $\mathrm{Br}_{2}$ with $\mathrm{I}^{-}$(green peaks at masses 285, 287, 289 in Fig. 4).

$\mathrm{HOBr}$ conversion to $\mathrm{Br}_{2}$ is quantified by comparing changes in $\mathrm{HOBr}$ and $\mathrm{Br}_{2}$ signals caused by interactions with inlet surfaces. $\mathrm{HOBr}$ to $\mathrm{Br}_{2}$ conversion occurs solely on the inlet walls. $\mathrm{Br}_{2}$ signals are unaffected by $\mathrm{HOBr}$ addition directly into the flow tube, demonstrating that conversion of $\mathrm{HOBr}$ to $\mathrm{Br}_{2}$ does not occur in the ion-molecule reaction region. In the flow tube, low Reynolds number and residence time $(0.17 \mathrm{~s})$ reduces surface interaction. Sampling $\mathrm{HOBr}$ through the $70 \mathrm{~cm}$ long aircraft inlet lowers $\mathrm{HOBr}$ and increases $\mathrm{Br}_{2}$ signals (Fig. 5). Since $\mathrm{Br}_{2}$ does not react on the Teflon inlet, $\mathrm{HOBr}$ conversion to $\mathrm{Br}_{2}$ is quantitative in these laboratory studies. Figure 5 shows the measured signals from $0.4 \mathrm{ppbv} \mathrm{Br}_{2}$ and $2.5 \mathrm{ppbv} \mathrm{HOBr}$ in $5 \mathrm{slm}$ dry $\mathrm{N}_{2}$ that are admitted directly into the instrument (labeled Instru-

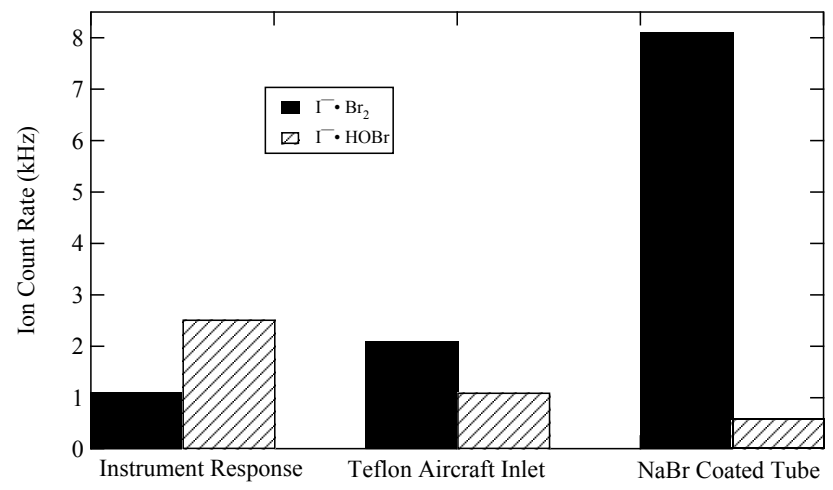

Fig. 5. $\mathrm{Br}_{2}$ (black) and $\mathrm{HOBr}$ (diagonal lines) signals when $0.4 \mathrm{ppbv} \mathrm{Br}_{2}$ and $2.5 \mathrm{ppbv} \mathrm{HOBr}$ in dry $\mathrm{N}_{2}$ are admitted directly into the flow tube (labeled Instrument Response), flow through the Teflon aircraft inlet, and flow through a $\mathrm{NaBr}$-coated tube.

ment Response), into the inlet (Teflon Aircraft Inlet), or into a Pyrex tube coated with $\mathrm{NaBr}$. The conversion of $\mathrm{HOBr}$ to $\mathrm{Br}_{2}$ on $\mathrm{Br}^{-}$coated surfaces is five times more efficient than conversion on the Teflon aircraft inlet (Fig. 5). On other materials, including glass, aluminum, stainless steel, polyvinylidene fluoride (PVDF), and several other types of Teflon, $\mathrm{HOBr}$ converts to $\mathrm{Br}_{2}$ with equal or greater efficiency than with PFA Teflon. On nylon, however, $\mathrm{HOBr}$ is removed without substantial $\mathrm{Br}_{2}$ production.

Since $\mathrm{HOBr}$ is converted to $\mathrm{Br}_{2}$ on the aircraft inlet, $\mathrm{Br}_{2}$ signals at the detector represent a sum of atmospheric $\mathrm{Br}_{2}$ and $\mathrm{HOBr}$. Conversion efficiency is enhanced by wall contact, which is not quantified for all flight conditions. Furthermore, conversion of $\mathrm{HOBr}$ to $\mathrm{Br}_{2}$ increases dramatically on bromide-coated surfaces, yet the extent to which the aircraft inlets were bromide-coated is not known. Therefore, $\mathrm{HOBr}$ to $\mathrm{Br}_{2}$ conversion efficiency is uncertain but no greater than unity. Consequently, $\mathrm{Br}_{2}$ signals represent a lower limit of the sum of atmospheric $\mathrm{HOBr}+\mathrm{Br}_{2}$, which is called active bromine below.

In-flight diagnostics performed by the WP-3D I- CIMS include mass scans from 215-295 amu once every $90 \mathrm{~min}$. These were performed to assess mass spectrometer and ion chemistry stability, interferences from other compounds, and possible detection of other molecules. As an example, Fig. 6 shows mass spectra obtained over the Arctic Ocean north of Barrow on 19 April. Ozone mixing ratios were $12 \mathrm{ppbv}$ at $150 \mathrm{~m}$ altitude and $50 \mathrm{ppbv}$ at $1.7 \mathrm{~km}$. In the ozone-depleted air, $\mathrm{I}^{-} \cdot \mathrm{Br}_{2}$ ions were elevated, but clusters of $\mathrm{I}^{-}$with $\mathrm{BrO}$, $\mathrm{HOBr}$, and $\mathrm{BrCl}$ were not elevated above detection limits. The similarity of all spectra, absence of interferences near the product ion masses used for bromine detection, and unique isotopic signature of $\mathrm{Br}$ demonstrate that bromine was enhanced in ozone-depleted air and was detected as $\mathrm{Br}_{2}$. 
The two CIMS instruments that used $\mathrm{SF}_{6}^{-}$chemistry recorded similarly large $\mathrm{Br}_{2}$ signals. The $\mathrm{Br}_{2}$ measurements from the two CIMS instruments on the WP-3D were in quantitative agreement. Both instruments use the same calibration sources, so the correlation slopes between the two measurements do not reveal absolute accuracy. But high correlation coefficients (e.g., $r=0.86$ on 19 April) indicate that elevated $\mathrm{Br}_{2}$ signals are not artifacts of one instrument's ion chemistry or scrubbing materials. Thus, either atmospheric $\mathrm{Br}_{2}$ or conversion of $\mathrm{HOBr}$ to $\mathrm{Br}_{2}$ on the inlets of both CIMS instruments caused the elevated $\mathrm{Br}_{2}$ signals (called active bromine here).

\section{Results}

\subsection{Ozone depletion}

Ozone depletion is identified and categorized by comparing ozone mixing ratios in the MBL to values in the lower free troposphere, where ozone was never substantially depleted and variability was low. For example, between 1 and $2 \mathrm{~km}$ altitude on the five arctic WP-3D flights, average ozone mixing ratios were $54 \pm 9$ ppbv, with a $33-73$ ppbv range. In the MBL, ozone was often considerably lower than these free tropospheric levels. Major ozone depletion $\left(\mathrm{O}_{3}<4 \mathrm{ppbv}\right.$, as defined in the work of Ridley et al., 2003) was encountered on three WP-3D flights: 12 April, 15 April, and 18 April, for 71,25 , and $13 \mathrm{~min}$, respectively. Partial ozone depletion $\left(4<\mathrm{O}_{3}<20 \mathrm{ppbv}\right)$ was measured on all 5 arctic WP-3D flights, for a total of 10-67 min on each flight. In total, major ozone depletions were sampled for $1.8 \mathrm{~h}$, and partial ozone depletions were sampled for $2.7 \mathrm{~h}$. The map showing the five WP-3D aircraft flights that sampled the arctic boundary layer illustrates the location of ozone-depleted air (Fig. 1). Ozone was usually depleted at low altitudes over the Arctic Ocean. The exception was on 18 April, when ozone was not depleted in the MBL (indicated by the gaps along the flight track in Fig. 1). Unique to this flight, winds were predominately from land to the south, and ozone-rich air was advected over the ocean. Similarly, ozone-depleted air was sometimes transported inland when winds were from the north, as shown by the colored markers over land on 15 April. Above $300 \mathrm{~m}$ altitude ozone was nearly always greater than $30 \mathrm{ppbv}$.

Observations from the DC- 8 were similar. Ozone-depleted air was encountered in the MBL on six of the seven DC8 flights in the arctic, with major ozone depletions sampled on 3 flights. In total, the DC- 8 sampled major ozone depletions for $0.7 \mathrm{~h}$ and partial ozone depletions for $1.2 \mathrm{~h}$. The DC- 8 measurements also show that ozone depletion $\left(\mathrm{O}_{3}<20 \mathrm{ppbv}\right)$ was confined to the MBL. On all seven flights in the arctic, ozone was always greater than 33 ppbv above $1 \mathrm{~km}$ altitude.

Ozone depletion is identified here only when ozone was less than 20 ppbv. However, both aircraft regularly observed

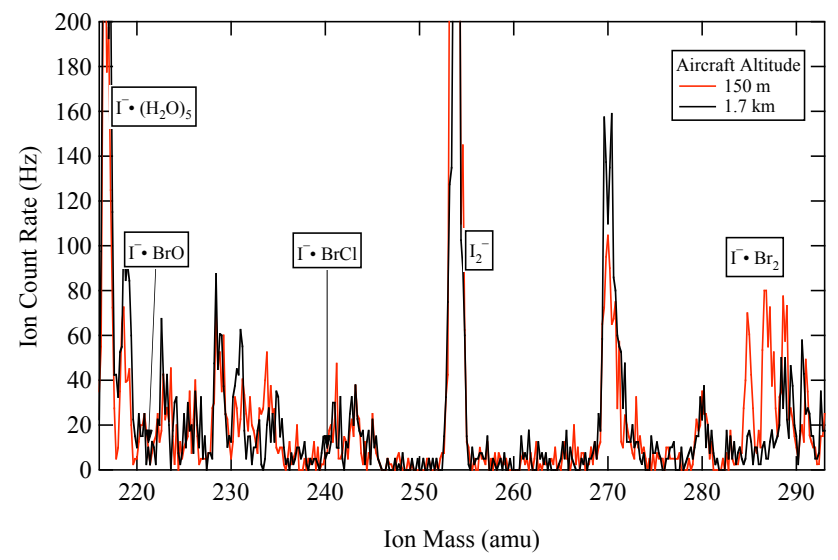

Fig. 6. Mass spectra obtained in flight at $1.7 \mathrm{~km}$ (black) and $150 \mathrm{~m}$ (red) altitude over the Arctic Ocean north of Barrow on 19 April. The WP-3D aircraft was in the MBL and ozone was depleted $\left(\mathrm{O}_{3}=12 \mathrm{ppbv}\right)$ at $150 \mathrm{~m}$ altitude.

ozone levels both in and above the MBL that were between $20-40 \mathrm{ppbv}$ and lower than the average lower tropospheric values. These slight reductions in ozone mixing ratios, which are not analyzed here, also may have been caused by bromine chemistry, followed by transport and dilution of ozone-depleted air. In the MBL, extremely low ozone values were occasionally observed. Both the DC-8 and WP-3D measured $\mathrm{O}_{3}<1 \mathrm{ppbv}$ on two flights and $\mathrm{O}_{3}<0.1 \mathrm{ppbv}$ on one flight.

\subsection{Bromine distributions and speciation}

The compounds and reactions involved in ozone depletion chemistry are investigated with speciated bromine measurements. Active bromine, which represents a lower limit of the sum $\mathrm{HOBr}+\mathrm{Br}_{2}$, was consistently enhanced in the MBL when ozone was depleted (Fig. 1). Active bromine measured along the WP-3D flight tracks (Fig. 1b) was co-located with ozone-depleted air (Fig. 1a). BrO measured from the WP-3D aircraft was usually less than active bromine, and $\mathrm{BrCl}$ levels were typically less than the 2 pptv detection limit (Fig. 7). Above $300 \mathrm{~m}$ altitude (gray lines in Fig. 1a), active bromine was below the 2 pptv detection limit (gray lines in Fig. 1b) indicating little transport of active bromine out of the MBL.

The relationship between active bromine and photolysis rates is examined to assess the relative contribution of $\mathrm{Br}_{2}$ and $\mathrm{HOBr}$ to active bromine. $\mathrm{Br}_{2}$ and $\mathrm{BrO}$ photolysis rates calculated from actinic flux measurements varied from $0.02 / \mathrm{s}$ to $0.06 / \mathrm{s}$, while $\mathrm{HOBr}$ photolysis rates were approximately 30 times slower (e.g., Lehrer et al., 2004; Martinez et al., 1999). Models show that rapid $\mathrm{Br}_{2}$ photolysis should restrict daytime $\mathrm{Br}_{2}$ to the bottom few $\mathrm{cm}$ of the atmosphere (Lehrer et al., 2004). Since $\mathrm{Br}$ recombination or $\mathrm{BrO}$ self reaction that forms $\mathrm{Br}_{2}$ is slow compared to photolysis, $\mathrm{Br}_{2}$ is predicted to be elevated only in close proximity to its surface 


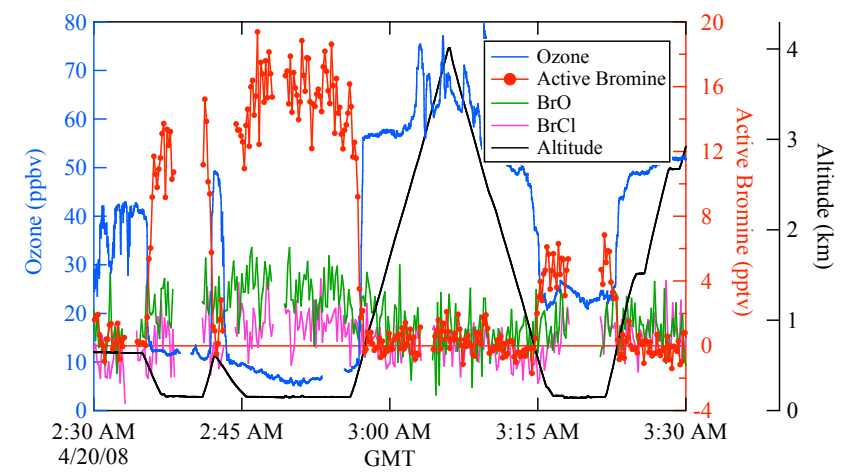

Fig. 7. $1 \mathrm{~h}$ time series of measurements obtained over the Arctic Ocean $300 \mathrm{~km}$ north of Barrow, Alaska on 19 April. $1 \mathrm{~s}$ measurements of ozone (blue) and aircraft altitude (black), and $10 \mathrm{~s}$ averages of active bromine (red), $\mathrm{BrO}$ (green), and $\mathrm{BrCl}$ (pink) are shown.

source. Since the time required for air to travel from the surface to aircraft altitudes $(\sim 100 \mathrm{~m})$ is many $\mathrm{Br}_{2}$ photolysis lifetimes, atmospheric $\mathrm{Br}_{2}$ should be near zero in these daytime aircraft measurements. And if $\mathrm{Br}_{2}$ were elevated, its abundance ought to depend upon the large $\mathrm{Br}_{2}$ photolysis rate, $j_{\mathrm{Br}_{2}}$, which varied with latitude, time, cloud cover, and surface albedo. For example, the aircraft flew over open ocean leads in the ice, which had much lower albedo than arctic ice. The reduction in reflected light over the leads caused rapid and large ( $>30 \%$ ) reductions in $j_{\mathrm{Br}_{2}}$ that should alter $\mathrm{Br}_{2}$ mixing ratios. However, active bromine did not vary with $j_{\mathrm{Br}_{2}}$, suggesting that there was little contribution from $\mathrm{Br}_{2}$ to active bromine. Therefore, the measured active bromine is likely HOBr.

Bromine measurements from the DC- 8 show similar distributions and enhancements. In ozone-depleted air sampled in the MBL over the Arctic Ocean, active bromine, $\mathrm{BrO}$, and soluble bromide were elevated. $\mathrm{BrO}$ levels (typically $<10$ pptv) were low compared to soluble bromide, which ranged from 10-40 pptv. Although several compounds could be responsible for the measured soluble bromide, both the active bromine and soluble bromide observations are consistent with the presence of $\mathrm{HOBr}$ in ozone-depleted air.

\subsection{Vertical distributions}

Altitude profiles further illustrate the confinement of ozone depletion and bromine enhancement to the MBL. The WP3D measurements shown in Fig. 7 illustrate that all bromine compounds were zero, within measurement uncertainty, just above the MBL. Very steep gradients in both ozone and active bromine occurred at the MBL top. For example, active bromine dropped from tens of pptv to zero and ozone increased from less than $10 \mathrm{ppbv}$ to $40 \mathrm{ppbv}$ between the MBL and above $600 \mathrm{~m}$ altitude (at $02: 42$ and before $02: 35$ in Fig. 7). The DC-8 also measured elevated active bromine in the MBL and values below detection limit above.

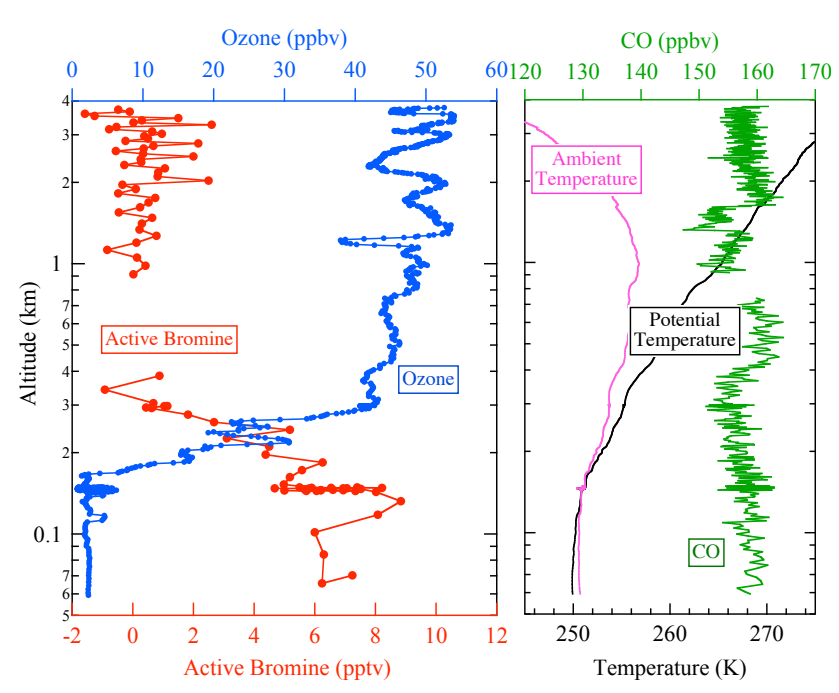

Fig. 8. $1 \mathrm{~s}$ measurements of $\mathrm{O}_{3}$ (blue), potential temperature (black), ambient temperature (pink), and CO (green) versus altitude during a descent of the WP-3D aircraft from $4 \mathrm{~km}$ to $60 \mathrm{~m}$ altitude on 12 April 2008. Red symbols are $10 \mathrm{~s}$ averages of active bromine. The gap in bromine data occurred during a $60 \mathrm{~s}$ instrument zero.

Boundary layer meteorology plays an important role in determining the vertical extent of ozone-depleted air. Figure 8 shows $1 \mathrm{~s}$ measurements of ozone, temperature, potential temperature, and $\mathrm{CO}$, and $10 \mathrm{~s}$ averages of active bromine during a WP-3D descent from $4 \mathrm{~km}$ to $60 \mathrm{~m}$ altitude. These measurements were obtained on 12 April over the Arctic Ocean at approximately $75^{\circ} \mathrm{N}, 145^{\circ} \mathrm{W}$ (Fig. 1) and approximately $560 \mathrm{~km}$ north of the Alaskan coast. The MBL was well-mixed, as indicated by near-constant potential temperature between $60-200 \mathrm{~m}$. Above the well-mixed layer, a strong temperature inversion of about $5^{\circ} \mathrm{C}$ over $500 \mathrm{~m}$ (Fig. 8) formed a stable layer that inhibited mixing between the boundary layer and the free troposphere above. Below the temperature inversion over the ocean, ozone was depleted and active bromine was enhanced. Above the MBL ozone was $40-55$ ppbv and active bromine was below detection limits. Similar altitude profiles were obtained on the five flights shown in Fig. 1, both at coastal locations and over the Arctic Ocean hundreds of $\mathrm{km}$ from the Alaskan coast. Other trace gases exhibit little difference in concentration between the MBL and the free troposphere. For example, $\mathrm{CO}$ mixing ratios averaged $158 \pm 2 \mathrm{ppbv}$ over the entire vertical profile shown in Fig. 8.

Variations with altitude were not apparent for many species because their mixing ratios were usually near instrument detection limits below $1 \mathrm{~km}$ over the Arctic Ocean. BrO and $\mathrm{BrCl}$ were below detection limits throughout the vertical profile shown in Fig. 8, averaging $-0.9 \pm 2.6$ pptv and $-0.5 \pm 2.3$ pptv respectively. Ozone depletion was observed in clean background air, and low mixing ratios of $\mathrm{NO}, \mathrm{NO}_{2}$, and $\mathrm{SO}_{2}$ were typical for most of the sampling in the MBL. 
$\mathrm{NO}, \mathrm{NO}_{2}$, and $\mathrm{SO}_{2}$ were equivalent to zero, within measurement uncertainties, over the time period shown in Fig. 7, with average values of $2 \pm 8$ pptv, $16 \pm 17 \mathrm{pptv}$, and $13 \pm 270 \mathrm{pptv}$, respectively.

\subsection{Bromine-ozone relationship}

The relationship between ozone and each halogen compound was unique, and these relationships were consistent on all WP-3D flights into the arctic. Figure 9 shows $10 \mathrm{~s}$ averages of active bromine (A), $\mathrm{BrCl}(\mathrm{B})$, and $\mathrm{BrO}(\mathrm{C})$ versus ozone. When ozone was greater than $40 \mathrm{ppbv}$, both active bromine and $\mathrm{BrCl}$ were at or below detection limits, while $\mathrm{BrO}$ increased at the highest ozone levels. In ozone-depleted air, which was measured only in the MBL, active bromine was consistently enhanced with values that reached $20 \mathrm{pptv}$. $\mathrm{BrCl}$ remained at or below detection limits, and $\mathrm{BrO}$ was usually less than 5 pptv. BrO mixing ratios measured here in ozonedepleted air were considerably lower than many previous reports. When $\mathrm{O}_{3}<4 \mathrm{ppbv}$, measurements of $\mathrm{BrO}$ from the WP-3D averaged $-0.3 \pm 1$ pptv, and those from the DC- 8 averaged $2 \pm 3$ pptv. When ozone depletion was less complete $\left(4<\mathrm{O}_{3}<20 \mathrm{ppbv}\right)$, BrO mixing ratios were higher, averaging $0.9 \pm 1.6 \mathrm{pptv}$ (WP-3D) and $3 \pm 4$ pptv (DC-8). In contrast, long-path measurements have observed $\mathrm{BrO}$ mixing ratios up to ten times greater in ozone-depleted air (e.g. Hausmann and Platt, 1994; Tuckermann et al., 1997).

The largest enhancements in active bromine and $\mathrm{BrO}$ in the MBL were observed on 19 April, when the meteorology differed considerably from the other days. On 19 April, the temperature inversion was higher $(500 \mathrm{~m})$, the MBL air was warmer $\left(-12^{\circ} \mathrm{C}\right)$ and the winds were stronger $(16 \mathrm{~m} / \mathrm{s})$ compared to the four other days, when the temperature inversion occurred between 200 and $250 \mathrm{~m}$, the MBL temperatures were -20 to $-15^{\circ} \mathrm{C}$, and wind speeds were $2-8 \mathrm{~m} / \mathrm{s}$. The largest enhancements in $\mathrm{BrO}$ above the MBL were also sampled by the WP-3D on 19 April. Elevated ozone and $\mathrm{BrO}$ were measured at $7.4 \mathrm{~km}$ in air that was influenced by the stratosphere. In this stratospheric intrusion, ozone reached $152 \mathrm{ppbv}$ and was anti-correlated with $\mathrm{CO}$, which dropped to 91 ppbv. $30 \mathrm{~s}$ averages of $\mathrm{BrO}$ reached a maximum of $7 \mathrm{pptv}$.

\section{Discussion and summary}

\subsection{Geographical extent of ozone depletion}

Measurements here over the Alaskan Arctic are consistent with those from the Canadian Arctic. Ozone depletion in the springtime has been reported as a persistent feature of the MBL over the Canadian Arctic (Hopper et al., 1998; Bottenheim and Chan, 2006; Leaitch et al., 1994; Ridley et al., 2003). Similarly, measurements here show that ozone was regularly depleted in the MBL over the Arctic Ocean north of Alaska. The WP-3D aircraft measured ozone depletion above the Chukchi Sea (as far south and west as $67^{\circ} \mathrm{N}$,

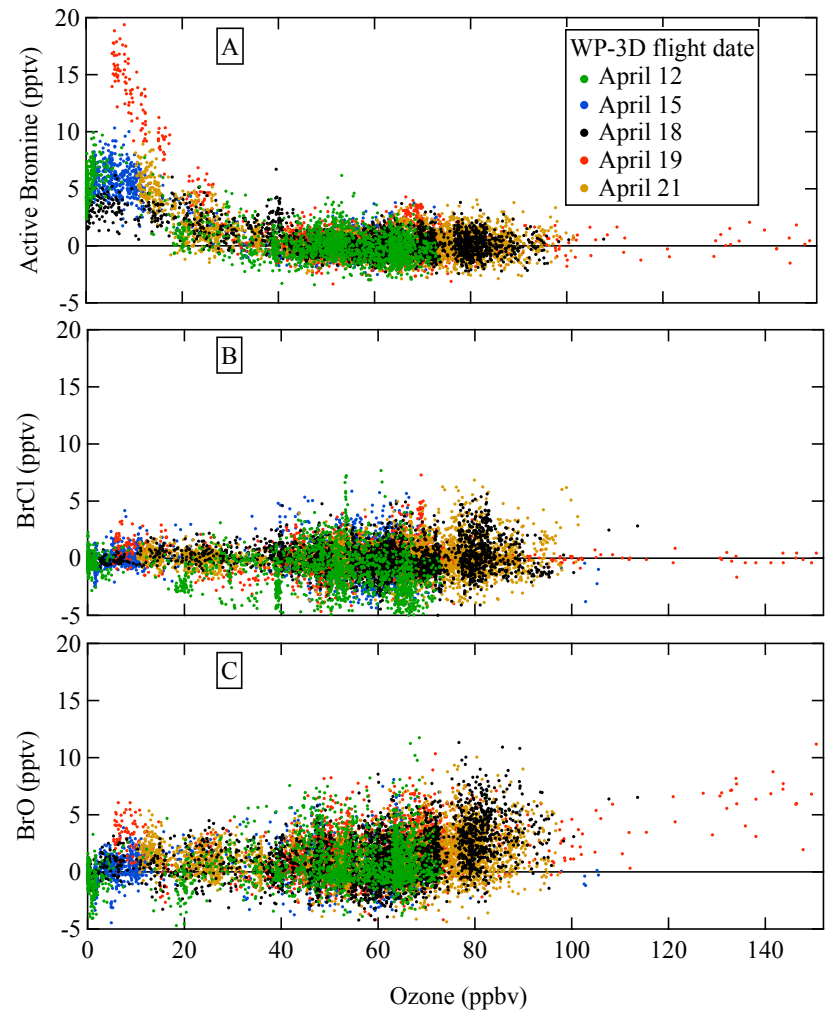

Fig. 9. $10 \mathrm{~s}$ averages of active bromine (a), $\mathrm{BrCl}(\mathbf{b})$, and $\mathrm{BrO}(\mathbf{c})$ versus ozone from five WP-3D flights that included sampling in the MBL over the Arctic Ocean.

$165^{\circ} \mathrm{W}$ ), Beaufort Sea (as far east as $125^{\circ} \mathrm{W}$ ), coastal areas (for example, $71^{\circ} \mathrm{N}, 151^{\circ} \mathrm{W}$ near Barrow, Alaska), and hundreds of $\mathrm{km}$ from land (as far as $75^{\circ} \mathrm{N}$, north of the Alaskan Coast). In all of these cases, ozone depletion was confined to the lower few hundred meters of the atmosphere in the MBL. Ozone depletion was observed in air masses with temperatures that ranged from $-22^{\circ} \mathrm{C}$ to $-10^{\circ} \mathrm{C}$, suggesting that ozone depletion can occur over a wide range of temperatures, as has been noted previously (Simpson et al., 2007; Bottenheim et al., 2009).

\section{2 $\mathrm{HOBr}$ and $\mathrm{Br}_{2}$ measurements}

This study might lead to new speciated measurements of inorganic bromine and assist with the interpretation of previous reports of photochemically active bromine compounds. $\mathrm{HOBr}$ is shown to convert rapidly to $\mathrm{Br}_{2}$ on many types of Teflon, glass, and metal, even without bromide coatings applied to the materials' surfaces. Sampling air without introducing wall contact eliminates this reaction, although this is not always feasible. Alternatively, rapid conversion can be exploited to quantitatively convert all $\mathrm{HOBr}$ to $\mathrm{Br}_{2}$ by sampling air through a bromide-coated inlet to measure the sum $\mathrm{HOBr}+\mathrm{Br}_{2}$. And $\mathrm{Br}_{2}$ can be measured independently by sampling air through a nylon wool filter, since $\mathrm{HOBr}$ is 
removed on nylon, but $\mathrm{Br}_{2}$ is not. From these two measurements, $\mathrm{HOBr}$ can be determined from the difference between $\left(\mathrm{HOBr}+\mathrm{Br}_{2}\right)$ and $\mathrm{Br}_{2}$.

$\mathrm{HOBr}$ conversion on instrument surfaces may have contributed to previous observations of $\mathrm{Br}_{2}$. For example, up to 27 pptv of $\mathrm{Br}_{2}$ was observed after sunrise in ozone-depleted air by a CIMS technique that sampled a large gas flow through a $9 \mathrm{~m}$ long Teflon inlet (Foster et al., 2001). If $\mathrm{HOBr}$ were present in the atmosphere and the sampled air contacted the inlet walls, $\mathrm{HOBr}$ conversion likely contributed to the $\mathrm{Br}_{2}$ signal. Similarly, measurements of $\mathrm{HOBr}$ and $\mathrm{Br}_{2}$ using glass cells (Impey et al., 1999) also may have been affected by the conversion of $\mathrm{HOBr}$ to $\mathrm{Br}_{2}$ on surfaces.

\subsection{Bromine chemistry}

Several inorganic bromine compounds participate in chemical reactions that lead to ozone depletion in the springtime over the Arctic Ocean, and several of those compounds were observed here. Previous observations of $\mathrm{BrO}$ and total bromine in ozone-depleted air show that $\mathrm{BrO}$ accounts for a widely varying fraction of total bromine (Martinez et al., 1999; Hausmann and Platt, 1994). But speciated measurements of inorganic bromine other than $\mathrm{BrO}$ are sparse (Barrie et al., 1994; Impey et al., 1999; Foster et al., 2001), and the relative contribution of each bromine compound to total bromine is not certain. $\mathrm{HOBr}$ is often comparable to or larger than $\mathrm{BrO}$ during the daytime measurements reported here, assuming that the measured active bromine is only $\mathrm{HOBr}$. The predominance of $\mathrm{HOBr}$ over $\mathrm{Br}_{2}$ is consistent with previous measurements (Impey et al., 1999), and $\mathrm{HOBr}$ has been predicted to be more abundant than $\mathrm{BrO}$ in ozone depleted air (Martinez et al., 1999). However, the BrO mixing ratios measured here (typically a few pptv in ozone-depleted air) from three different aircraft CIMS instruments were much lower than the tens of pptv that has been observed previously from ground-based instruments. The causes for low $\mathrm{BrO}$ values have not been determined, but several factors may explain these results. If $\mathrm{BrO}$ were confined to the lowest altitudes of the MBL, these aircraft observations at approximately $100 \mathrm{~m}$ altitude may have been above regions with enhanced $\mathrm{BrO}$. Low $\mathrm{BrO}$ could be caused by losses on inlets exposed to ambient air, although $\mathrm{BrO}$ losses on Teflon inlets were measured to be insignificant in the laboratory. Lastly, the weak correlation between ozone and $\mathrm{BrO}$ (Hausmann and Platt, 1994) and $\mathrm{BrO}$ variations between $0-30 \mathrm{pptv}$ in ozone-depleted air (Tuckermann et al., 1997) make it possible that these few aircraft flights may have sampled only those ozone depletions with low BrO. However, the observed increase in active bromine indicates the presence of bromine chemistry in the sampled ozone-depleted air masses, where both $\mathrm{BrO}$ and $\mathrm{HOBr}$ are predicted to be enhanced (e.g. Martinez et al., 1999; Evans et al., 2003; Calvert and Lindberg, 2003; Lehrer et al., 2004).
Bromine partitioning between $\mathrm{HBr}, \mathrm{BrO}$, and $\mathrm{HOBr}$ may reveal whether ozone depletion has terminated or is still occurring in a sampled air mass. Several models examined the temporal behavior of halogen-initiated ozone depletion and show $\mathrm{HBr}, \mathrm{BrO}$, and $\mathrm{HOBr}$ enhancements of many pptv during daytime in ozone-depleted air (Martinez et al., 1999; Calvert and Lindberg, 2003; Evans et al., 2003; Fan and Jacob, 1992; Shepson et al., 1996; Lehrer et al., 2004), with relative abundances that vary with the duration of ozone depletion chemistry. Bromine accumulates as $\mathrm{HBr}$ when ozone depletion has terminated (Lehrer et al., 2004; Martinez et al., 1999), and the presence of $\mathrm{HOBr}$ may indicate that ozone depletion chemistry is still in progress. Improved measurements of these halogen compounds as suggested above might allow for identification and better characterization of halogen chemistry that depletes ozone.

Acknowledgements. The Air Quality and the Climate Research and Modeling Programs of the National Oceanic and Atmospheric Administration (NOAA) supported the WP-3D measurements. We are grateful to Hendrik Fuchs for measuring $\mathrm{Br}_{2}$ to calibrate the permeation devices and Chuck Brock for helpful discussions. The NASA Tropospheric Chemistry Program supported the DC-8 measurements.

Edited by: J. W. Bottenheim

\section{References}

Barrie, L. A., Bottenheim, J. W., Schnell, R. C., Crutzen P. J., and Rasmussen, R. A.: Ozone destruction and photochemical reactions at polar sunrise in the lower Arctic atmosphere, Nature, 334, 138-141, 1988.

Barrie, L. A., Li, S.-M., Toom, D. L., Landsberger, S., and Sturges, W.: Lower tropospheric measurements of halogens, nitrates and sulphur oxides during Polar Sunrise Experiment 1992, J. Geophys. Res., 99, 25,453-25,467, 1994.

Bottenheim, J. and Chan, H. M.: A trajectory study into the origin of spring time Arctic boundary layer ozone depletion, J. Geophys. Res., 111, D19301, doi:10.129/2006JD007055, 2006.

Bottenheim, J. W., Netcheva, S., Morin, S., and Nghiem, S. V.: Ozone in the boundary layer air over the Arctic Ocean: measurements during the TARA transpolar drift 20062008, Atmos. Chem. Phys., 9, 4545-4557, doi:10.5194/acp-9-4545-2009, 2009.

Brock, C., Cozic, J., Bahreini, R., Brioude, J., de Gouw, J. A., Fahey, D. W., Ferrare, R., Froyd, K. D., Holloway, J. S., Hübler, G., Lack, D., Lance, S., Middlebrook, A. M., Montzka, S. A., Murphy, D. M., Neuman, J. A., Nowak, J., Peischl, J., Ryerson, T. B., Schwarz, J. P., Sodemann, H., Spackman, R., Stohl, A., Veres P., and Warneke C.: Arctic Aerosol Properties Measured in Spring 2008 During the Aerosol, Radiation, and Cloud Processes Affecting Arctic Climate (ARCPAC) Project, in preparation, 2010.

Calvert, J. G. and Lindberg, S. E.: A modeling study of the mechanism of the halogen-ozone-mercury homogeneous reactions in the troposphere during the polar spring, Atmos. Environ., 37, 4467-4481, 2003. 
Dibb, J. E., Ziemba, L. D., Luxford, J., and Beckman, P.: Bromide and other ions in the snow, firn air, and atmospheric boundary layer at Summit during GSHOX, Atmos. Chem. Phys. Discuss., 10, 13609-13642, doi:10.5194/acpd-10-13609-2010, 2010.

Donohoue, D. L., Bauer, D., Cossairt, B., and Hynes, A. J.: Temperature and Pressure Dependent Rate Coefficients for the Reaction of $\mathrm{Hg}$ with $\mathrm{Br}$ and the Reaction of $\mathrm{Br}$ with $\mathrm{Br}$ : A Pulsed Laser Photolysis-Pulsed Laser Induced Fluorescence Study, J. Phys. Chem. A, 110, 6623-6632, 2006.

Eigen, M. and Kustin, K.: The kinetics of halogen hydrolysis, J. Am. Chem. Soc., 84(8), 1355-1361, doi:10.1021/ja00867a005, 1962.

Evans, M. J., Jacob, D. J., Atlas, E., et al.: Coupled evolution of $\mathrm{BrO}_{\mathrm{x}}-\mathrm{ClO}_{\mathrm{x}}-\mathrm{HO}_{\mathrm{x}}-\mathrm{NO}_{\mathrm{x}}$ chemistry during bromine-catalyzed ozone depletion events in the arctic boundary layer, J. Geophys. Res., 108(D4), 8368, doi:10.129/2002JD002732, 2003.

Fan, S.-M. and Jacob, D. J.: Surface ozone depletion in Arctic spring sustained by bromine reactions on aerosols, Nature, 359, 522-524, 1992.

Fickert, S., Adams, J. W., and Crowley, J. N.: Activation of $\mathrm{Br}_{2}$ and $\mathrm{BrCl}$ via uptake of $\mathrm{HOBr}$ onto aqueous salt solutions, J. Geophys. Res., 104, 23, 719-23,727, 1999.

Foster, K. L., Plastridge, R. A., Bottenheim, J. W., Shepson, P. B., Finlayson-Pitts, B. J., and Spicer, C. W.: The role of $\mathrm{Br}_{2}$ and $\mathrm{BrCl}$ in surface ozone destruction at polar sunrise, Science, 291, 471-474, 2001.

Hausmann, M. and Platt, U.: Spectroscopic measurement of bromine monoxide and ozone in the high Arctic during Polar Sunrise Experiment 1992, J. Geophys. Res., 99, 25399-25413, 1994.

Hopper, J. F., Barrie, L. A., Silis, A., Hart, W., Gallant, A. J., and Dryfhout, H.: Ozone and meteorology during the 1994 Polar Sunrise Experiment, J. Geophys. Res., 103, 1481-1492, 1998.

Huey, L. G.: Measurement of trace atmospheric species by chemical ionization mass spectrometry: Speciation of reactive nitrogen and future directions, Mass Spec. Reviews, 26, 166-184, 2007.

Huey, L. G., Hanson, D. R., and Howard, C. J.: Reactions of SF 6 and $\mathrm{I}^{-}$with atmospheric trace gases, J. Phys. Chem., 99(14), 5001-5008, 1995.

Impey, G. A., Mihele, C. M., Anlauf, K. G., Barrie, L. A., Hastie, D. R., and Shepson, P. B.: Measurements of photolyzable halogen compounds and bromine radicals during the Polar Sunrise Experiment 1997, J. Atmos. Chem., 34, 21-37, 1999.

Jacob, D. J., Crawford, J. H., Maring, H., Clarke, A. D., Dibb, J. E., Emmons, L. K., Ferrare, R. A., Hostetler, C. A., Russell, P. B., Singh, H. B., Thompson, A. M., Shaw, G. E., McCauley, E., Pederson, J. R., and Fisher, J. A.: The Arctic Research of the Composition of the Troposphere from Aircraft and Satellites (ARCTAS) mission: design, execution, and first results, Atmos. Chem. Phys., 10, 5191-5212, doi:10.5194/acp-10-5191-2010, 2010.

Jobson, B. T., Niki, H., Yokouchi, Y., Bottenheim, J., Hopper, F., and Leaitch, R.: Measurements of C2-C6 hydrocarbons during the Polar Sunrise 1992 Experiment: Evidence for $\mathrm{Cl}$ atom and $\mathrm{Br}$ atom chemistry, J. Geophys. Res., 99(D12), 25355-25368, 1994.

Jones, A. E., Anderson, P. S., Begoin, M., Brough, N., Hutterli, M. A., Marshall, G. J., Richter, A., Roscoe, H. K., and Wolff, E. W.: BrO, blizzards, and drivers of polar tropospheric ozone depletion events, Atmos. Chem. Phys., 9, 4639-4652, doi:10.5194/acp-94639-2009, 2009.
Keil, A. D. and Shepson, P. B.: Chlorine and bromine atom ratios in the springtime Arctic troposphere as determined from measurements of halogenated volatile organic compounds, J. Geophys. Res., 111, D17303, doi:10.129/2006JD007119, 2006.

Kim, S., Huey, L. G., Stickel, R. E., et al.: Measurement of $\mathrm{HO}_{2} \mathrm{NO}_{2}$ in the free troposphere during the Intercontinental Chemical Transport Experiment-North America, J. Geophys. Res., 112, D12S01, doi:10.1029/2006JD0076762007, 2007.

Leaitch, W. R., Barrie, L. A., Bottenheim, J. W., Li, S. M., Shepson, P. B., Muthuramu, K., and Yokouchi, Y.: Airborne observations related to ozone depletion at polar sunrise, J. Geophys. Res., 99, 25499-25517, 1994.

Lehrer, E., Hönninger, G., and Platt, U.: A one dimensional model study of the mechanism of halogen liberation and vertical transport in the polar troposphere, Atmos. Chem. Phys., 4, 24272440, doi:10.5194/acp-4-2427-2004, 2004.

Liao, J., Huey, L. G., Schueur, E., and Dibb, J. E.: Characterization of soluble bromide measurements during ARCTAS, in preparation, 2010.

Mahajan, A. S., Plane, J. M. C., Oetjen, H., Mendes, L., Saunders, R. W., Saiz-Lopez, A., Jones, C. E., Carpenter, L. J., and McFiggans, G. B.: Measurement and modelling of tropospheric reactive halogen species over the tropical Atlantic Ocean, Atmos. Chem. Phys., 10, 4611-4624, doi:10.5194/acp-10-46112010, 2010.

Martinez, M., Arnold, T., and Perner, D.: The role of bromine and chlorine chemistry for arctic ozone depletion events in $\mathrm{Ny}$ lesund and comparison with model calculations, Ann. Geophys., 17, 941-956, doi:10.1007/s00585-999-0941-4, 1999.

Mochida, M., Akimoto, J., van den Bergh, H., and Rossi, M. J.: Heterogeneous kinetics of the uptake of $\mathrm{HOBr}$ on solid alkali metal halides at ambient temperature, J. Phys. Chem. A, 102, 4819-4828, 1998.

Neuman, J. A., Huey, L. G., Dissly, R. W., Fehsenfeld, F. C., Flocke, F., Holecek, J. C., Holloway, J. S., Hubler, G., Jakoubek, R., Nicks Jr., D. K., Parrish, D. D., Ryerson, T. B., Sueper, D. T., and Weinheimer, A. J.: Fast-response airborne in situ measurements of $\mathrm{HNO}_{3}$ during the Texas air Quality Study, J. Geophys. Res., 107(D20), 4436, doi:10.1029/2001JD001437, 2002.

Oltmans, S. J.: Surface ozone measurements in clean air, J. Geophys. Res., 86(C2), 1174-1180, 1981.

Orlando, J. J., Burkholder, J. B., Bopegedera, A. M. R. P., and Howard C. J.: Infrared measurements of $\mathrm{BrO}$ (Х2П3/2), J. Mol. Spectrosc., 145, 278-289, 1991.

Platt, U. and Honninger, G.: The role of halogen species in the troposphere, Chemosphere, 52, 325-338, 2003.

Read, K. A., Mahajan, A. S., Carpenter, L. J., et al.: Extensive halogen-mediated ozone destruction over the tropical Atlantic Ocean, Nature, 453, 1232-1235, doi:10.1038/nature07035, 2008.

Ridley, B. A., Atlas, E. L., Montzka, D. D., et al.: Ozone depletion events observed in the high latitude surface layer during the TOPSE aircraft program, J. Geophys. Res., 108(D4), 8356, doi:10.1029/2001JD001507, 2003.

Roberts, J. M., Osthoff, H. D., Brown, S. S., and Ravishankara, A. R.: $\mathrm{N}_{2} \mathrm{O}_{5}$ Oxidizes Chloride to $\mathrm{Cl} 2$ in Acidic Atmospheric Aerosol, Science, 321, 1059, doi:10.1126/science.1158777, 2008.

Sander, R. and Crutzen, P. J.: Model study indicating halogen ac- 
tivation and ozone destruction in polluted air masses transported to the sea, J. Geophys. Res., 101, 9121-9138, 1996.

Sander, S. P., Friedl, R. R., Ravishankara, A. R., Golden, D. M., Kolb, C. E., Kurylo, M. J., Molina, M. J., Moortgat, G. K., Keller-Rudek, H., Finlayson-Pitts, B. J., Wine, P. H., Huie, R. E., and Orkin, V. L.: Chemical Kinetics and Photochemical Data for Use in Atmospheric Studies Evaluation Number 15, JPL Publication 06-2, 2006.

Shepson, P. B., Sirju, A.-P., Hopper, J. F., Barrie, L. A., Young, V., Niki, H., and Dryfhout H.: Sources and sinks of carbonyl compounds in the Arctic Ocean boundary layer: Polar Ice Floe Experiment, J. Geophys. Res., 101, 21081-21089, 1996.

Simpson, W. R., von Glasow, R., Riedel, K., Anderson, P., Ariya, P., Bottenheim, J., Burrows, J., Carpenter, L. J., Frie, U., Goodsite, M. E., Heard, D., Hutterli, M., Jacobi, H.-W., Kaleschke, L., Neff, B., Plane, J., Platt, U., Richter, A., Roscoe, H., Sander, R., Shepson, P., Sodeau, J., Steffen, A., Wagner, T., and Wolff, E.: Halogens and their role in polar boundary-layer ozone depletion, Atmos. Chem. Phys., 7, 4375-4418, doi:10.5194/acp-74375-2007, 2007.

Slusher, D. L., Huey, L. G., Tanner, D. J., Flocke, F. M., and Roberts, J. M.: A thermal dissociation-chemical ionization mass spectrometry (TD-CIMS) technique for the simultaneous measurement of peroxyacyl nitrates and dinitrogen pentoxide, J. Geophys. Res., 109, D19315, doi:10.1029/2004JD004670, 2004.
Stark, H., Lerner, B. M., Schmitt, R., Jakoubek, R., Williams, E. J., Ryerson, T. B., Sueper, D. T., Parrish, D. D., and Fehsenfeld, F. C.: Atmospheric in situ measurement of nitrate radical $\left(\mathrm{NO}_{3}\right)$ and other photolysis rates using spectroradiometry and filter radiometry, J. Geophys. Res., 112, D10S04, doi:10.1029/2006JD007578, 2007.

Steffen, A., Douglas, T., Amyot, M., Ariya, P., Aspmo, K., Berg, T., Bottenheim, J., Brooks, S., Cobbett, F., Dastoor, A., Dommergue, A., Ebinghaus, R., Ferrari, C., Gardfeldt, K., Goodsite, M. E., Lean, D., Poulain, A. J., Scherz, C., Skov, H., Sommar, J., and Temme, C.: A synthesis of atmospheric mercury depletion event chemistry in the atmosphere and snow, Atmos. Chem. Phys., 8, 1445-1482, doi:10.5194/acp-8-1445-2008, 2008.

Tuckermann, M., Ackermann, R., Golz, C., Lorenzen-Schmidt, H., Senne, T., Stutz, J., Trost, B., Unold, W., and Platt, U.: DOAS-observation of halogen radical-catalysed arctic boundary layer ozone destruction during the ARCTOC-campaigns 1995 and 1996 in Ny-Alesund, Spitsbergen, Tellus, 49B, 533-555, 1997.

Yang, X., Cox, R. A., Warwick, N. J., Pyle, J. A., Carver, G. D., O'Connor, F. M., and Savage, N. H.: Tropospheric bromine chemistry and its impacts on ozone: A model study, J. Geophys. Res., 110, D23311, doi:10.1029/2005JD006244, 2005.

Zeng, T., Wang, Y., Chance, K., Browell, E. V., Ridley B. A., and Atlas, E. L.: Widespread persistent near-surface ozone depletion at northern high latitudes in spring, Geophys Res. Lett., 30, 2298, doi:10.1029/2003GL018587, 2003. 